\title{
RESPONSABILIDADE E JULGAMENTO
}

\author{
$\underline{\text { Responsibility and judgment }}$
}

Maria Ximèna Alvarez*

ARENDT, Hannah. Responsabilidade e julgamento. São

Paulo: Companhia das Letras, 2004

O livro intitulado Responsabilidade e julgamento constitui uma das coletâneas feitas com os últimos textos escritos por esta filósofa alemã antes da sua morte em dezembro de 1975. Alguns destes são palestras, outras aulas ou conferencias, que ela ditou nesse ano e foram achadas no seu escritório, ou seja, suas últimas reflexões e análises.

Essas indagações, em torno do tema da ética e da moral, da responsabilidade civil, das culpas coletivas refletidas no silêncio, começaram a ser realizadas logo após da publicação do livro Eichmann em JerusalémUm relato sobre a banalidade do Mal, em 1963. O relato sobre o julgamento do criminoso burocrata Eichmann, um simples dente de engrenagem na maquinaria nazista, coloca em questão, novas temáticas que não tinham ainda sido abordadas em seus trabalhos anteriores. Por sua parte, essa mera "reportagem" gerou grandes divisões na comunidade judaica internacional, assim como entre os grandes nomes da intelectualidade da época, e afastando-a de quase todos os círculos judeus no mundo.

Na reportagem sobre ao julgamento de Eichmann Arendt menciona, entre outras questões, a colaboração dos judeus proeminentes das comunidades européias com os nazistas e a feitura de listas de prisioneiros a serem enviados aos campos de concentração, fatos que ela registra a partir das abordagens da defesa no julgamento de Eichmann.

* Doutoranda em História no Instituto Latino Americano (LAI) da Universidade Livre de Berlim e bolsista do Deutscher Akademischer Austauschdienst 
Outro ponto altamente questionado do livro foi o fato de Arendt classificar e Eichmann como um ser comum e não como um monstro. Contrariamente ao que se podia supor, este funcionário responsável por milhares de mortes nos campos de concentração não era uma besta horrível como a promotoria argumentava, senão um homem comum que carecia da capacidade de pensar. Para Arendt, esse tipo de homen, sem a qualidade do diálogo consigo mesmo, como assim a define o pensar, constitui o ser mais perigoso, mais do que qualquer dos piores criminosos, condição que ela definiu como a "banalidade do mal". Ao contrário do que entenderam seus críticos, isso não era uma desculpa pelo que Eichmann fizera, nem a consideração de que "há um Eichmann em todos nós", senão um alerta sobre o perigo que se incorre quando um homem deixa de ter essa comunicação consigo mesmo, ou seja, quando ele perde a capacidade de pensar.

Segundo a autora, a controvérsia causada a partir de seu livro deriva de uma total incompreensão do texto, e também de uma análise sentimental e emocional dos fatos relatados.

Sabes tan bien como yo cuan a menudo los que se limitan a informar de ciertos hechos desagradables son acusados de falta de sensibilidad, de falta de corazón o de falta de lo que tú llamas Herzenstakt. Los dos sabemos, en otras palabras, cuán a menudo esas emociones se utilizan para ocultar la verdad de los hechos." responde Arendt a uns de seus criticos. (ARENDT, 2005. p. 146) ${ }^{1}$

A partir do julgamento e a análise que ela faz de Eichmann, assim como da reação da sociedade alemã após os julgamentos dos chamados "criminosos entre nós", surgem no seu pensamento novas questões e reflexões, que são abordadas neste livro Responsabilidade e Julgamento. Com ele, podese entender o lugar dos "Eichmann" nas maquinarias do terror nazista, sendo esse livro mais uma contribuição para o esclarecimento desse debate.

A primeira parte versa sobre as questões emanadas do conceito de responsabilidade, refletindo sobre as questões fundamentais da filosofia socrática, cristã, kantiana e nietzschiana. São abordados temas sobre a res-

1 Intercâmbio epistolar entre Gershom Scholem e Hannah Arendt, a propósito da publicação do livro de Eichmann. Cf. ARENDT, Hannah. Una revisión de la historia judia y otros ensayos. Buenos Aires: Paidós, 2005. 
ponsabilidade pessoal e política sob uma ditadura. Arendt discorre também sobre responsabilidade individual e a noção de responsabilidade coletiva, discordando desta última, pois onde "todos somos culpados, nenhum é".

Quando desaparecem todos os parâmetros sociais e morais, a lógica conhecida entre o que está bem e o que está mal, Arendt questiona o que acontece com a capacidade humana de julgamento, no caso de existir essa capacidade de julgar racionalmente? Por outra parte, qual é o meu lugar para julgar e minha responsabilidade numa burocracia onde eu sou um dente de engrenagem.? "A burocracia é infelizmente o mando de ninguém e, por essa mesma razão, talvez a forma menos humana e mais cruel dos governos" (ARENDT, p. 94)

Para Arendt, a responsabilidade pessoal sob a ditadura não permite a transferência de responsabilidade do homem para o sistema. Aqueles poucos que julgaram por si mesmos foram os não participantes, os que ficaram fora de todas as esferas da vida pública. A capacidade de julgamento se vincula ao pensar, ao diálogo silencioso de mim comigo mesmo. Os que não participaram de tais crimes, entenderam que não poderiam cometer crimes porque seriam incapazes de conviver com um criminoso, ou seja, eles mesmos. Realizaram um ato de desobediência civil, o que, conforme a autora, é uma forma de resistência não violenta. "Essas pessoas não são nem heroínas nem santas, e se acabam se tornando mártires, o que, claro, pode ocorrer, isso acontece contra a sua vontade. Além do mais no mundo em que conta o poder, elas são impotentes". (ARENDT,p. 143)

Arendt também questiona a mudança de valores produzida pela sociedade alemã, ao trocar, rapidamente, o "Não matarás" pelo "Sim, matarás". Neste aspecto, destaque-se a influência de Nietzsche, que entende a moralidade e a ética simplesmente como costumes e hábitos, que podem ser modificados e trocados por outros. "Eles simplesmente trocaram um sistema de valores por outro", diz Arendt (ARENDT, p. 107)

Outros dos conceitos analisados que remetem à tradição socrática, são os referidos ao mal e ao bem. A autora parte da moralidade socrática, a qual insiste que é melhor sofrer o mal do que o cometer "(...) se faço o mal, sou condenado a viver junto com um malfeitor numa intimidade insuportável, nunca posso me ver livre dele".

A essa afirmação se associa uma segunda: "melhor estar em desavença com o mundo inteiro do que, sendo Uma Só, estar em desavença comigo mesma", pois os homens pensantes têm e precisam da companhia 
de si mesmos. Aqueles outros que perderam a capacidade de pensar são aqueles capazes de fazer qualquer coisa, porque a sua falta de pensamento não os coloca no diálogo íntimo com o malfeitor, e esses são os mais perigosos.

A segunda parte do livro é, no meu entender, a mais polêmica. Composta de quatro artigos, dicute, primeiramente, em "Reflexões sobre Little Rock", a temática da integração racial nas escolas norte-americanas; em "O vigário: culpa pelo silêncio?", o silêncio culposo do papa Pio XII frente aos crimes nazistas; o lugar do criminoso direto, ou seja, o papel daqueles que atuaram em Auschwitz, a partir do prosseguimento dos "Julgamentos de Frankfurt"; e, finalmente, uma aguda crítica à sociedade norte-americana no contexto do bicentenário da República, sob o título "Tiro pela culatra".

Nas Reflexões sobre Little Rock, apresenta-se o seu julgamento, aliás, muito controvertido, sobre a integração de crianças negras nas escolas norte-americanas. Ela entende que essa integração forçada de um grupo dentro do outro, não gera outra coisa do que a transferência da problemática política do racismo dos adultos para as crianças. E entende também que essa igualdade forçada, ação dirigida pelo governo, atenta contra a liberdade dos pais de educarem seus filhos na companhia de quem eles quiseram. "Os direitos dos pais decidirem essas questões para os filhos até eles se tornarem adultos só são questionados pelas ditaduras". (ARENDT, p. 263)

A postura de Arendt, ao criticar a integração de crianças pretas com brancas foi muito criticada e constitui sua primeira controvérsia pública, já que fora publicada antes de Eichmann em Jerusalém.

Partindo da análise da peça de Rolf Hochhuth $O$ vigário, Arendt reflete sobre a culpabilidade do silêncio e a responsabilidade pessoal do Papa Pio XI sobre o não pronunciamento, sequer denúncia da parte do Vaticano sobre os acontecimentos terríveis do nazismo. Sendo o Papa a "autoridade espiritual mundial" de 400 milhões de legionários em toda a Terra, uma postura de condenação aos atos dos nazistas poderia ter modificado o comportamento dos cristãos, sobretudo na Europa católica do Leste. Além desse silêncio cúmplice da Igreja Católica, que sequer condenou o racismo ou o anti-semitismo, colaboraram com os nazistas na elaboração de listas de católicos com ascendência judaica. A partir de 1941, a segregação destes na Igreja alemã e sua conseqüente deportação, assim alerta Arendt, tornou-se um fato. 
Uma versão mais reduzida do Julgamento de Eichmann em Jerusalém constitui o artigo sobre os criminosos de Auschwitz. Esses réus eram quem articulava as ordens emanadas dos altos cargos da burocracia nazista. Conforme destaca Arendt, tanto a opinião pública quanto a legal inclinouse a considerar que os criminosos burocratas -como Eichmann- eram mais culpados do que aqueles que operavam na maquinaria de extermínio. Por outra parte, os julgamentos de Auschwitz alumbraram a questão da iniciativa individual, no sistema da burocracia terrorista, a qual tentava excluir qualquer ato que não fosse estipulado, portanto, assassinos burocratas. A realidade foi exatamente o contrário, a regra dos campos de extermínio foi a imprevisibilidade e a arbitrariedade. "Tudo mudava quase de dia para dia. Dependia do oficial encarregado, do líder da chamada, do líder do bloco e de seus estados de espírito" (ARENDT, p. 320), ou seja, cada um podia decidir por si mesmo: ser bom ou ser mau em Auschwitz.

O último texto do livro constitui um dos últimos discursos púbicos de Arendt, este referido ao bicentenário da República americana. A autora demonstra-se muito crítica da realidade do país, como a desastrosa guerra de Vietnã, a crise econômica e os curtos alcances democráticos da era de Maccarthy, bem como sobre o escândalo Watergate. Ela tinha valorizado positivamente a Revolução americana em contraposição ao fracasso da Revolução francesa, pois, segundo ela, na primeira pôde se verificar o triunfo dos valores da Liberdade. No contexto do bicentenário, essa grandeza dos Pais Fundadores, conforme Arendt, deveria constituir um excelente meio de "iluminar o pensamento e a ação dos homens em tempos sombrios".

A importância desta obra reside na aproximação das questões de ética e moral, da responsabilidade coletiva em vista de fatos contemporâneos à realidade da autora. Partindo das suas reflexões teóricas, ela entende e analisa o mundo em que vivemos e que eticamente ela nos convida a atuar. A obra traduz o engajamento de Arendt no sentido de pensar sobre os desafios modernos, e daí seu caráter polêmico. 